\title{
SMART CITIES AND THE EUROPEAN VISION
}

\author{
Carmen Florina Fagadar ${ }^{1}$, Diana Teodora Trip ${ }^{1}$, Darie Gavrilut ${ }^{1}$, Daniel Badulescu ${ }^{2}$ \\ ${ }^{1}$ Doctoral School of Economics, Faculty of Economic Sciences, University of Oradea, \\ Oradea, Romania \\ ${ }^{2}$ Department of Economics and Business, Faculty of Economic Sciences, University of \\ Oradea, Oradea, Romania \\ carmen.fagadar@emanuel.ro \\ dianateodora.trip@gmail.com \\ darie.gavrilut@gmail.com \\ dbadulescu@uoradea.ro
}

\begin{abstract}
Cities are one of the main factors influencing the economic development and prosperity of societies. Smart cities, fueled by innovation and the Internet of Things, are built on three pillars - improving the residents' quality of life, business competitiveness, and ensuring a sustainable environment. When applied within the six urban areas: economy, mobility, security, education, living conditions, and environment, cities can much faster make the transition to smart cities. The term smart city is often associated with the desire for accelerated modernization of various spatial and urban social interactions, the term "smart city" often being fuelled by technological developments. Proof of this are the terms used to define the same concept: "digital city", "e-communities", "intelligent city", "e-City", "wired city". However, a smart city is called upon to respond to the needs of cities and societies alike to approach challenges in a novel and creative manner. The motivations for transforming existing cities into smart ones are obvious and straightforward. They come on one hand, from the threats of current demographic phenomena (population growth, migration, public health, safety, and living conditions), and also from the opportunities of solutions that can be brought by technological developments and innovation, transformations of generations (new "Digital" generations), and civic involvement (participation and inclusion) in the management of modern cities. Thus, the meaning associated to the name of the smart city does not only overlap with the idea of modernization and expansion, but also wants to combine, simultaneously, competitiveness and sustainable urban development. In the present study, by building upon a European vision as regards the development of smart cities, we have attempted to build an image of the European envisioned smart city, which is to be planned out and sought after through a series of strategic partnerships for innovation. Not only is the European vision detailed, but Romanian specific urban development and smart city tendencies shall also be briefly analyzed in this paper.
\end{abstract}

Keywords: urban development; smart; digitalization; sustainability.

JEL Classification: O18; Q56; $R 11$.

\section{Introduction}

Cities are the main factors in the economic development and prosperity of society, probably an expression of what Paul Krugman called concentration, as the most striking feature of the geography of economic activity [...], economic production, is remarkably concentrated in space (Krugman, 1991:5). Cities are the culmination of public creativity on a variety of issues - from economic opportunities and the provision of quality education, to solving traffic, jobs, tax cuts, increasing safety, and creating a healthy and sustainable environment for the new generations. A smart city, fuelled by innovation and the Internet of Things, is built on 
three pillars - improving the residents' quality of life, business competitiveness, and ensuring a sustainable environment. Applied within the six urban areas: economy, mobility, security, education, living conditions, and environment, they can give meaning to this considerable effort.

In the present study, informed by the European vision, we aimed to build an image of the smart city envisioned at the European level, planned out and sought after through a series of strategic partnerships for innovation, and stop briefly to evaluate the experiences of Romania in embodying smart urbanization. We started from the idea that smart city is not a process per se or an end point for the efforts of governmental and local authorities, specialized companies or citizens. Cities do not become smart by itself, but rather by capitalizing chances of development where technology and innovation primarily serve citizens.

Understanding the trends and transformations that can lead to this "smart" option of urban development, constraints, challenges, potential, threats, and opportunities can ensure the successful commitment and initiatives of the European Union and, respectively, of the Romanian authorities. Last but not least, a smart city is also the result of the efforts coming from cities' associations, civil society, businesses, academia, and citizens involved in creating smart, sustainable, and high-performance cities.

\section{Smart City - concept and context boundaries}

The term smart city is often associated with the desire for accelerated modernization of space and urban social interactions, which is fuelled by technological developments, especially of Information and Communications Technologies. Proof of this are the terms used to define the same concept: "digital city", "e-communities", "intelligent city", "e-City", "wired city". However, a smart city is called upon to respond to the need for cities to approach creatively and differently the challenges, be they novel, caused by globalization and integration (population growth, resource consumption, pollution, climate change, limited natural resources) be they old, unresolved or partially resolved such as congestion, waste management, utility network, public safety, etc. The meaning of the smart city does not only overlap with the idea of modernization and expansion, but also wants to combine, simultaneously, competitiveness and sustainable urban development (Giffinger et al., 2007). In other words, a smart city must use to its advantage, in a creative and revolutionary way, the offer and the characteristics of modernization, technology, and digital skills.

\subsection{Heading for the Smart City}

The motivations for transforming existing cities into smart ones are obvious. They come, on one hand, from the threats of current demographic phenomena - population growth, migration, public health, safety living conditions, sustainable development and mitigating pollution (Badulescu et al., 2019), but also from the possibilities of a solution that can be brought by the technological developments and innovation, transformations of generations (new "Digital" generations), and civic involvement (participation and inclusion) in the management of modern cities.

The growth of the world's urban population is the most important challenge facing urban managers and planners, as well as the citizens of the cities. The proportion of the world's urban population will increase from 55\% in 2018 (around 4.2 billion people) to $68 \%$ by 2050 (see Figure 1). 


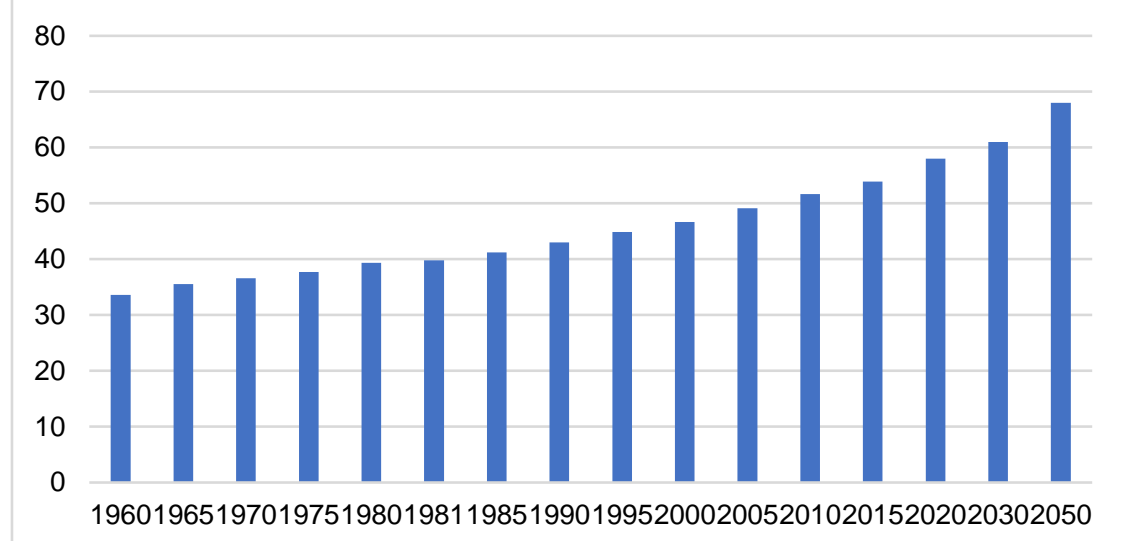

Figure 1: Evolution of the world's urban population (\% of total population) between 1960 and 2050
Source:
World
Bank,
Urban
Population, https://data.worldbank.org/indicator/SP.URB.TOTL.IN.ZS, (2019)

Obs. For 2020 estimation, for 2030 and 2050 forecasts

In other words, in these conditions of global population's growth, practically speaking, in about three decades, the urban population of the world will almost double. By 2100 , about $85 \%$ of the world's population will live in cities, with the urban population growing from less than 1 billion in 1950 to 9 billion by 2100 (European Commission, 2019). In 2018, the most urbanized regions were: North America (82\%), Latin America and the Caribbean (81\%), Europe $(74 \%)$ and Oceania (68\%). Although Asia has a level of urbanization of only $49 \%$, it hosts $54 \%$ of the world's urban population. Europe's level of urbanization will increase from about $73 \%$ today, to about $78 \%$ in 2025 and to $83.7 \%$ in 2050 .

In the table below we presented comparatively (years interval 1990 - 2016), the size of the urban population, the percentage of the total population and the growth rate, as well as the situation of large urban agglomerations. The situation is related to the major geographical regions of the world, respectively depending on the level of development of that region, according to the World Bank methodology.

Table 1: Situation of the urban population, by major geographical regions and level of economic development, between 1990 and 2016 (mil. persons and \%)

\begin{tabular}{|c|c|c|c|c|c|c|c|c|c|}
\hline & \multicolumn{5}{|c|}{ Urban population } & \multirow{2}{*}{\multicolumn{2}{|c|}{$\begin{array}{c}\text { Population in } \\
\text { urban } \\
\text { agglomerations } \\
\text { of more than } 1 \\
\text { million } \\
\% \text { of total } \\
\text { population }\end{array}$}} & \multirow{2}{*}{\multicolumn{2}{|c|}{$\begin{array}{c}\begin{array}{c}\text { Population in } \\
\text { the largest } \\
\text { city }\end{array} \\
\% \text { of urban } \\
\text { population }\end{array}$}} \\
\hline & \multicolumn{2}{|c|}{ Millions } & \multicolumn{2}{|c|}{$\begin{array}{c}\% \text { of total } \\
\text { population }\end{array}$} & \multirow{2}{*}{$\begin{array}{c}\% \\
\text { growth } \\
2016\end{array}$} & & & & \\
\hline & 1990 & 2016 & 1990 & 2016 & & 1990 & 2016 & 1990 & 2016 \\
\hline World & 2272 & 4037 & 43 & 54 & 2,00 & 18 & 24 & 17 & 16 \\
\hline $\begin{array}{l}\text { East Asia \& } \\
\text { Pacific }\end{array}$ & 619 & 1318 & 34 & 57 & 2.30 & & & 17 & 12 \\
\hline $\begin{array}{l}\text { Europe } \quad \& \\
\text { Central Asia }\end{array}$ & 568 & 653 & 68 & 72 & 0.70 & 18 & 20 & 15 & 17 \\
\hline $\begin{array}{l}\text { Latin America } \\
\& \text { Caribbean }\end{array}$ & 312 & 504 & 71 & 80 & 1.30 & 34 & 38 & 25 & 23 \\
\hline $\begin{array}{l}\text { Middle East \& } \\
\text { North Africa }\end{array}$ & 140 & 281 & 55 & 65 & 2.40 & 23 & 26 & 28 & 26 \\
\hline
\end{tabular}


The Annals of the University of Oradea. Economic Sciences TOM XXX, $1^{\text {st }}$ Issue, July 2021

\begin{tabular}{|l|r|r|r|r|r|r|r|r|r|}
\hline \hline North America & 209 & 294 & 75 & 82 & 1.00 & 42 & 46 & 10 & 8 \\
\hline South Asia & 284 & 587 & 25 & 33 & 2.50 & 11 & 15 & 10 & 11 \\
\hline $\begin{array}{l}\text { Sub-Saharan } \\
\text { Africa }\end{array}$ & 139 & 400 & 27 & 39 & 4.0 & 12 & 15 & 29 & 27 \\
\hline Low income & 77 & 212 & 23 & 32 & 3.90 & 10 & 12 & 35 & 31 \\
\hline $\begin{array}{l}\text { Lower middle } \\
\text { income }\end{array}$ & 559 & 1164 & 30 & 40 & 2.60 & 12 & 16 & 17 & 16 \\
\hline $\begin{array}{l}\text { Upper middle } \\
\text { income }\end{array}$ & 890 & 1690 & 43 & 65 & 2.10 & 17 & 29 & 14 & 12 \\
\hline High income & 746 & 970 & 74 & 81 & 0.80 &.. &.. & 20 & 19 \\
\hline
\end{tabular}

Source: World Bank, 3.12. World Development Indicators: Urbanization, available at http://wdi.worldbank.org/table/3.12\#

Urban centres/cities currently produce almost $80 \%$ of the world's carbon emissions and account for most of the world's more than 2 billion cars. Cities lose, through inefficient and used networks, about $50 \%$ of the water supply, and shopping malls and residential buildings consume about $1 / 3$ of the world's energy (IBM, 2012).

According to United Nations Development Programme (UNDP), the rapid growth of cities a result of population growth and increasing migration - has led to a boom that has determined the creation of mega-cities (see Table 1), especially in developing countries, slums becoming a significant feature of urban life. Thus, in UNDP's Goal 11: Sustainable cities and communities, sustained efforts are needed to create sustainable cities, with career and business opportunities, safe and affordable housing, and to build resilient societies and economies. They can only be achieved with investments in public transport, ecological and safe public spaces, a participatory and inclusive urban management planning (United Nations Development Programme, 2020).

However, we must not interpret cities only through the challenges of congestion, waste management, degradation of living conditions, or the uncontrolled expansion of a slum-type urbanization. The economic power of cities is impressive (OECD, 2015) because it is also here that the most important resources are found (material, social or intellectual) which can be employed in finding solutions to the problems listed above. OECD studies show that the world's cities generate $80 \%$ of all economic growth and have a huge potential to implement and develop modern technologies and infrastructure that make better use of resources. Thus, with each doubling of the population size, the level of productivity of a city increases by $2-5 \%$, due to better distribution of labour, education systems, the stimulation of entrepreneurship, and the spreading of ideas (OECD, 2015). Cities are beginning to realize that problems can only be solved by involving high-tech promoters and through civic participation - they are beginning to partner with private corporations such as IBM, Cisco, $\mathrm{GE}$, and Siemens to collect, analyse and use data to improve decision-making (European Commission, 2019).

It is relatively difficult to estimate how many cities can be considered (sufficiently) smart, as long as a reference point is not clearly defined, i.e. a minimum number of implemented projects or the size of the elements included. However, according to some estimates, in 2017 there were over 250 smart city projects in 178 cities around the world (European Commission, 2019). Among them, Europe is the best performing geographical area, with 12 cities ranked among the top 25 smart cities according to IESE "Cities in Motion Index" (Berrone et al., 2019). And for the future, Europe's ambition is remarkable - it aims to have more than 300 smart cities by 2020-2021 and plans the largest number of investments in smart city projects globally. But also other countries, such as countries in Asia (China and India in particular), Africa or Latin America, plan to develop or even build about 200 smart cities by 2022-2025, with an impact on a population of almost 2 billion people. In economic terms, this means a huge market, which is expected to exceed 2 trillion dollars by 2025 . 
The market for "smart" equipment and applications has a huge growth potential, being estimated for 2020 at over 1,000 billion dollars. Most IT companies have adjusted their research / development strategies to meet the challenges of the "smart" world. Large IT, telecommunications and energy companies such as IBM, Cisco, Siemens, Hitachi, Toshiba, Schneider Electric, General Electric, Oracle, Microsoft (and the list may go on), have been involved, with huge investments, in the development of applications and equipment that are necessary for this global transformation (Pușcașu, 2016). These companies' involvement can be a basis and an engine for future economic growth in a model much closer to the goals of sustainability and environmental protection. Concepts such as sustainability and quality of life now prevail over other indices and objectives, and this means that cities need to start thinking and planning how to be closer to the citizens, more environmentally friendly, how to rationally use the resources they have and generate income, and must do all these, simultaneously (Pușcașu, 2016).

\subsection{Framing the Smart City concept}

Besides the rationale on the development of smart cities when looking at the opportunities to be embraced and challenges to be faced, a clear conceptualization of the smart city is needed to build upon. Against a backdrop of a clearly framed concept, proper planning and evaluation can be conducted.

The term smart city is quite ambiguous due to the very wide area of fields it refers to (Vrabie and Dumitrascu, 2018); there is not yet a definition that includes all aspects of a smart city (Russo et al., 2014) and, implicitly, we cannot talk about similar approaches of cities on their way to becoming smart.

According to Russo et al. (2014) the first use of the term smart city appears in 2007, in the work of Giffinger et al., on the Ranking of European medium-sized cities (Giffinger et al., 2007). It referred to the creation and connection of human capital, social capital, and information and communication technology (IT\&C) infrastructure, with the aim of generating greater and more sustainable urban development as well as a better quality of life. In 2008 , Hollands (2008) considered that smart cities use network infrastructure to improve economic and political efficiency, while enabling social, cultural and urban development. In other words, "a city can be called "smart" when investments in human, social capital, traditional and modern communication infrastructure fuel sustainable economic growth and a high quality of life, with wise management of natural resources, through participatory governance" (Schaffers et al., 2011; Russo et al., 2014).

A smart city can also be understood and defined in terms of system. Smart cities should be considered as systems of systems, marked by opportunities for the introduction of digital systems, intelligent responsiveness and optimization at all levels of system integration (William, 2013). However, smart city developers must take into account local communities, their pre-existing relationships with the urban place and realize that technology also has limits, and sometimes it does not fit on the personal or emotional space of the city. In other words, Smartness is a means to an end - improving the quality of urban life (Halegoua, 2020). The British Standards Institute (BSI) defines a smart city as an "efficient integration of physical, digital and human systems to build the environment necessary for the sustainable, prosperous and inclusive development of the future of its citizens" (British Standards Institution (BSI), 2014). CISCO sees smart cities as entities that adopt "scalable solutions that take into account the benefits of information and communication technology (IT\&C) to increase efficiency, reduce costs and improve quality of life" (Falconer and Mitchell, 2012).

Nevertheless, the concept and process of transforming urban agglomerations into smart cities is not without its critics and ignoring them or sending them to a register of frustrations or maladaptation seems to be a wrong and even dangerous action. Thus, according to Michael McGuire (2018), the "smart city" is a "hyper-spatial" city in which the social world is 
not only connected, but hyper-connected. This means that the risks they generate are not just those of an everyday physical space, but dangers with multidimensional properties, far exceeding those associated with mass dataveillance, or the hacking of a home hub by techsavvy burglars. When citizens are multi-interconnected, the emerging system risks generating debilitation as much as facilitation, deformation rather than information, and insecurity rather than security (McGuire, 2018).

The risk of a stronger separation of urban space from the rural one, concentration of power and opportunities and educational segregation is also captured by John Mock in the suggestive phrase Smart City - Stupid Countryside, an alarm signal and a call to wisdom and balance (Mock, 2016). For Bruce Sterling, the term "smart city" is interesting, but it's not important enough because no one defines it. "Smart" seems to be a great political label, used by a modern alliance of left-wing urban planners and technology industrialists. It is rude and arrogant, because to consider someone "smart" just because is involved in the development of urban facilities or uses some applications means to make real entrepreneurs and innovators stupid or limited. For this author, the cities of the future will not be "smarter" or better designed, fair, clean, green, sustainable, safe, healthy, accessible or resilient, nor will they be based on high values of freedom, equality or fraternity. The smart city of the future will belong to the internet, the mobile cloud and a multitude of strange gadgets promoted by public administrators, largely for the sake of making cities more attractive to capital (Sterling, 2018). Understanding the threats and tempering the excesses, adapting the process so as to avoid or diminish unfavorable situations or dangers indicated by serious but reserved researchers regarding smart city solutions as a panacea for future development, seems the wisest philosophy and action.

\section{Smart City and the EU paradigm}

The journey to create smart cities and intelligent city ecosystems throughout Europe has long been an objective of European Commission. Its initiatives recognize the need for an integrated and coordinated approach to support policy making, both locally and at European level, to help understand application of advanced technologies and the opportunities they uncover, to present a design of a flexible, future-proof, European smart city.

\subsection{The European vision for Smart Cities}

The European Parliament study on smart cities emphasizes that a smart city is made up not only of components but also of people and ensuring the participation of citizens and relevant stakeholders in Smart City is another success factor (European Parliament, 2014). The same study also highlights the advantages and disadvantages of either increasing coordination (top-down approach) or increasing the opportunity for people to participate directly (bottom-up approach).

According to European Commission "a smart city is a place where traditional networks and services are made more efficient with the use of digital and telecommunication technologies for the benefit of its inhabitants and business" (European Commission, 2018). A smart city is a place where traditional networks and services are streamlined through the use of digital and telecommunications technologies, for the benefit of its inhabitants and businesses. In other words, such a city aims to make the most of information and communication technologies (IT\&C) for better use of resources and with less harmful emissions. It can do this through smarter urban transport networks, modern water supply equipment and systems, public lighting, building heating and, last but not least, waste disposal (see Figure 2). A smart city is served by an interactive and receptive administration, ensures the safety and comfort of the citizen in public spaces and provides facilities and resolution to the needs of all age groups, especially children and the elderly. 


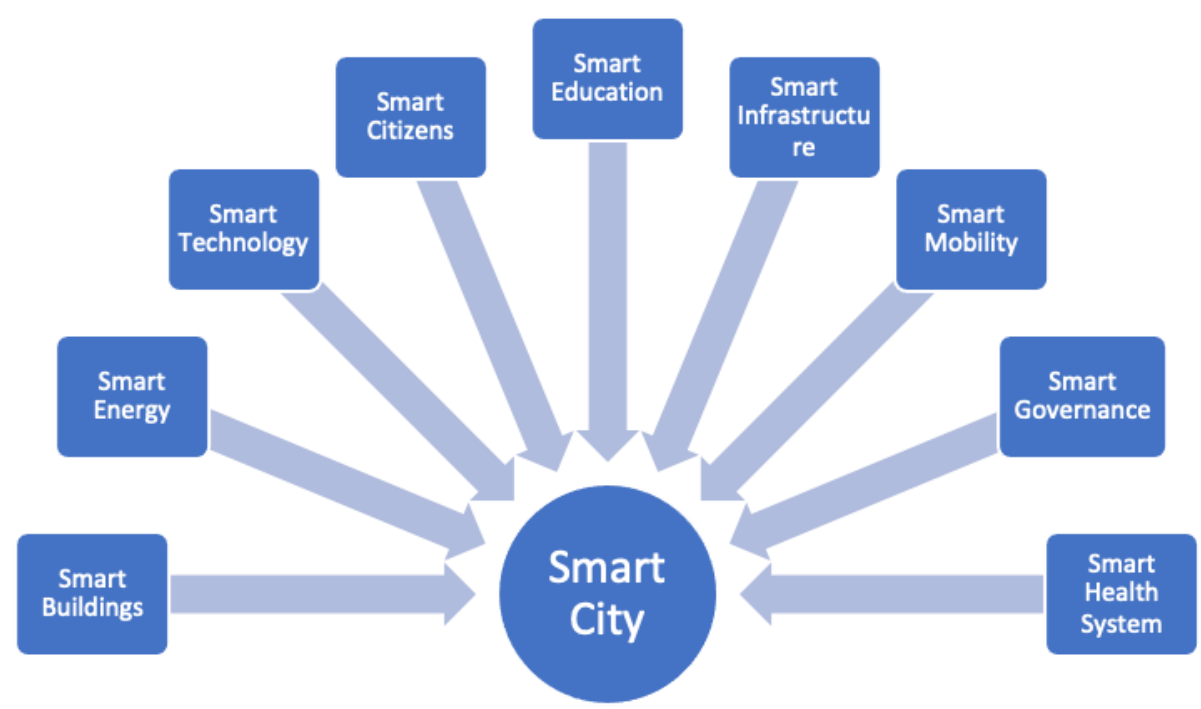

Figure 2: What defines a smart city?

Source: authors' elaboration

In Europe, the development of Smart Cities has two main actors: the cities themselves (especially the capitals of the member countries) and the European Union (as an institutional construction).

The study Mapping Smart Cities in the EU (European Parliament, 2014) details the role of the EU in this process and provides a comprehensive picture of the current situation in the European Union and some case studies of advanced cities in this regard (Amsterdam, Helsinki, Barcelona, Copenhagen, Manchester, Vienna). In 2015, the European Economic and Social Committee (EESC) adopted a document laying the foundations for a new strategy for the development and support of Smart City projects, called "Smart cities as a driver of a new European industrial policy" (European Economic and Social Committee (EESC), 2015). In order to support the development of smart cities across the EU, the EESC upholds supporting investment in such projects with existing public funds, European, national and regional funds, as well as by exploiting the opportunities offered by the European Fund for Strategic Investments (EFSI).

\subsection{Partnering for innovation}

To facilitate the process, the European Innovation Partnership on Smart Cities and Communities (EIP-SCC) has been set up, bringing together cities, industries and citizens, with the aim of improving the quality of urban life through more sustainable, integrated solutions (through applied innovation, better planning, more participatory approach, better energy efficiency, better transport solutions, smart use of IT\&C, etc.).

The European Innovation Partnership on Smart Cities and Communities (EIP-SCC) is an initiative supported by the European Commission that brings together cities, industries, small businesses (SME's), banks, research and, of course, citizens, to improve urban life through more sustainable integrated solutions. The partnership between key areas such as energy, transport and information and communication technologies (IT\&C) aims to catalyse progress in these closely related areas and provide new interdisciplinary opportunities to improve services that reduce energy and resource consumption (See Figure 3). The partnership includes applied innovation, better planning, a more participatory approach, 
greater energy efficiency, better transport solutions, smart use of information and communication technologies (IT\&C), etc. (European Commission, 2018).

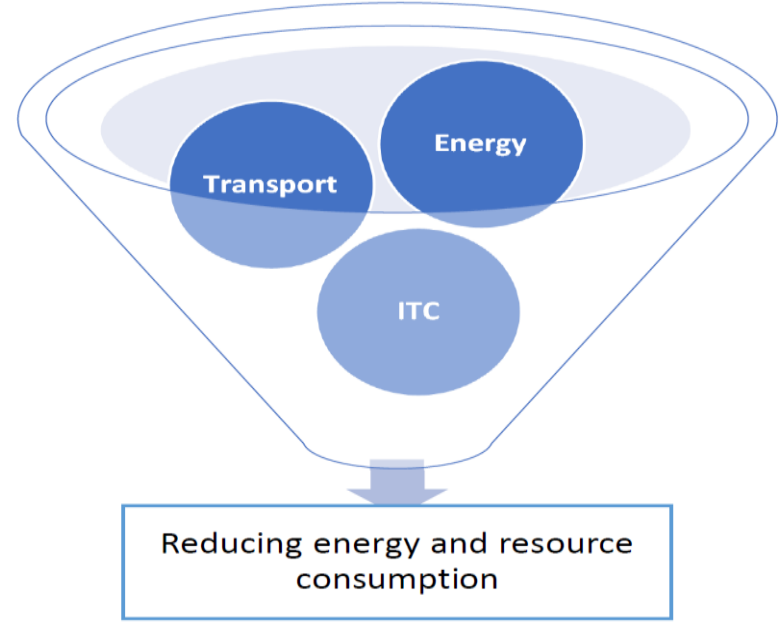

Figure 3: European innovation partnership on smart cities and communities (EIP-SCC) energy, transport and ITC to reduce energy and resource consumption

Source: Authors' elaboration based on European Innovation Partnership on Smart Cities and Communities (EIP-SCC)

The priorities of the partnership are sustainable urban mobility; sustainable districts and built environment; integrated infrastructures and processes in energy; information and communication technologies and transport; citizen focus; policy and regulation; integrated planning and management; knowledge sharing; open data governance; Standards; business models, procurement and funding (European Commission, 2018).

In addition to institutional initiatives, there is a lucrative online platform, Smart Cities in Europe, which provides training sessions, a roadmap, presents challenges, as well as good practices (HVB Communicatie Amsterdam, 2017), (SmartCityPlatform, 2018).

\section{Romania and the smart steps undertaken}

One of the first official documents attesting the concerns and clear orientation of government policies towards the digitalization of public administration, and implicitly towards smart cities, can be considered to be the National Research, Development and Innovation Strategy for 2014-2020 of the Romanian Government, published in October 2014 (Guvernul României, 2014). It contains, in the section Innovative solutions for the public sector, elements that can undoubtedly be considered the first guidelines and commitments in this field. Also, in 2014, the National Strategy on the Digital Agenda for Romania was adopted: Digital Agenda 2014-2020 for Romania (MCSI, 2014), and for its implementation, the Agency for the Digital Agenda of Romania was established (Pușcașu, 2016:12).

The Executive Unit for Financing Higher Education, Research, Development and Innovation (UEFISCDI), a public institution subordinated to the Ministry of National Education, is also involved, by conducting studies and coordinating, from an administrative point of view, some programs and subprograms from National Plan for Research, Development, Innovation, in the smart city area. 
Finally, in December 2016, the Ministry of Communications and Information Society (MCSI) launched the Smart City Guide for Romania - Smart Cities for Smart Communities (MCSI, 2016), which summarizes MCSI's vision on the use of "smart" technologies in the lives of human communities, for the purpose of sustainable development of the latter, in harmony with nature and the environment. Through this guide, MCSI aims to "stimulate the use of innovative technologies with a positive impact on the quality of the life of citizens, environmental protection, business development and sustainable development of local communities and society in general" (MCSI, 2016:4).

Of course, there are other initiatives, regulations and guidelines issued by government authorities, official bodies, and public scientific institutions, which outline government efforts in this area of digitalization of public administration and, implicitly, in the field of smart cities. However, they would remain only decisions with partial or non-integrated implementation, if this picture lacked private initiatives (companies and non-governmental organizations), citizens, associations committed to implementing dedicated solutions and, of course, cities and associations of cities determined to become (or at least to start becoming) smart.

Thus, an associative structure that also provides a lucrative online platform is the Romanian Association for Smart City and Mobility (2019). This portal is a good starting point for any local public authority and provides an overview of the applicability of digital technologies in everyday life, to increase the citizens' quality of life as well as the efficiency of resource consumption. Another Romanian online platform is Smart Cities of Romania (2019), which proposes a Smart National Strategy for Smart Cities in Romania and an Incubator for Public Administrations, Research Institutions and Private Initiatives.

The business environment is represented by numerous multinational companies and leaders of the Romanian market that propose various "smart" solutions and initiatives: IBM, ZTE, Huawei, Luxten, NEC, Siemens, TeamNet, Bosch, Orange, Telekom, Cisco, UTI Group, Vodafone and many others (Pușcașu, 2016).

It should be emphasized here that an insufficiently valued and exploited resource is represented by the academic environment - Polytechnic University of Bucharest, Polytechnic University of Timisoara, SNSPA, Technical University of Cluj Napoca, BabeșBolyai University of Cluj-Napoca, University of Oradea being just some of the higher education institutions that are very active in this field. Their involvement is not only theoretical - through courses, studies, articles, conferences in these fields, which bring together experts, researchers, public decision makers - but also through people interested, especially the young generation, in extremely thought-provoking and challenging debates for the future of the cities and the citizens' quality of life. The academic environment is also involved in very practical ways, through the development and implementation of smart solutions adapted to urban agglomerations, as well as through the implementation of solid projects (the vast majority with EU and national funding), often in cooperation with local public authorities (Badulescu et al, 2015). These projects take into account either the urban environment in which they are located (streamlining local public transport, energy and water consumption, reservation systems, etc.), or their own developments in the university microcosmos (of a smart-campus type).

\section{Conclusions}

The term smart city is often associated with the desire for accelerated modernization of space and urban social interactions, especially based on Information and Communications Technologies. There are several concepts covering, more or less, the same meaning: "digital city", "e-communities", "intelligent city", "e-City", "wired city". However, a smart city is called upon to respond to the need for cities to approach creatively and differently the challenges caused by globalization and integration (population growth, resource 
consumption, pollution, climate change, limited natural resources. A smart isn't just a place based on modernization and ITC expansion, but an area who creatively combine, at the same time, competitiveness with sustainable urban development, open to cultural exchange, cooperation and tourism (Badulescu et al., 2014; Trip and Badulescu, 2020). In other words, a smart city must use to its advantage, in a creative and revolutionary way, the offer and the characteristics of modernization, technology and digital skills.

European Union has long been sustaining a vision for a smart urbanization, mobilising political leadership for adoption of digital transformation strategies and roadmaps, engaging citizens in shaping the city vision and strategy, partnering for innovation and creating vibrant markets for cutting-edge technology solution, upskilling people for the job market of the future. As we have seen, given the speed at which transformation take place, in proves vital for each and every city to strive to achieve the status of smart city as fast as they can. Another important aspect which has been discussed refers to the performance or development of particular region. Europe is the best performing geographical area, with 12 cities ranked among the top 25 smart cities according to IESE "Cities in Motion Index" (Berrone, et al., 2019). Differences still exist between the various European regions and cities, but constant collaboration between the public and the private sector will lead to increased efforts towards transforming cities into truly smart ones.

Even though there is no unified definition as to what makes a city truly smart, in the situation of Romania, we have seen that numerous steps are being taken by various local government throughout the country in order to digitize cities, to make them better adaptable at and for globalization trends, to involve citizens in the decision making process, to transform both the public and private sector from a technological standpoint, and to attract change agents/individuals into residing, moving, evolving and developing in these respective cities. Given that there are some disparities throughout the country in terms of how many cities are smart (in comparison to the cities that still strive to obtain this tile) and even though there still some challenges left, the effort undertaken by Romania as an European country and by the local government in this direction clearly points at numerous benefits that are still to come and which will be achieved by cities that concerns themselves in becoming smart.

\section{References}

1. Badulescu, A., Badulescu, D. and Borma, A. (2014) Enhancing cross-border cooperation through local actors' involvement. The case of tourism cooperation in Bihor (Romania)-Hajdú-Bihar (Hungary) Euroregion", Lex Localis, Vol. 12, No. 3, pp. 349-371. DOI: 10.4335/12.3.349-371.

2. Badulescu, D.; Badulescu, A. and Bucur, C.-A. (2015) Considerations on the Effectiveness of Cross-Border Cooperation in Public Order and Civil Protection Services. The Case of the Romanian Hungarian Border Area, Lex Localis-Journal of Local Self-Government, Vol. 13, No.3, pp. 559-578. https://doi.org/10.4335/13.3.559-578(2015).

3. Badulescu, D., Simut, R., Badulescu, A. and Badulescu, A.V. (2019) The relative effects of economic growth, environmental pollution and non-communicable diseases on health expenditures in European Union Countries, International Journal of Environmental Research and Public Health, Vol. 16, No. 24, 5115, https://doi.org/10.3390/ijerph16245115

4. Berrone, P., Ricart, J., Duch, A. and Carrasco, C. (2019) IESE Cities in Motion Index 2019, Spain: IESE Business School, University of Navarra, ST-509-E. DOI: 10.15581/018.ST-509.

5. British Standards Institute (BSI) (2014) Smart Cities - Vocabulary, [Online], Available: https://www.ipwea.org/HigherLogic/System/DownloadDocumentFile.ashx?DocumentFileKey=99c212 d8-7138-5b92-674a-3a5f6178fe3b [02 Feb 2020].

6. European Commission (2018) Smart cities, [Online], Available: https://ec.europa.eu/info/euregional-and-urban-development/topics/cities-and-urban-development/city-initiatives/smart-cities en [02 Feb 2020]. 
7. European Commission (2019) Developments and Forecasts on Continuing Urbanisation, [Online], Available: https://ec.europa.eu/knowledge4policy/foresight/topic/continuingurbanisation/developments-and-forecasts-on-continuing-urbanisation en [02 Feb 2020].

8. European Economic and Social Committee (EESC) (2015) Smart cities as a driver of a new European industrial policy, TEN/568-EESC-2015-568. Brussels: Official Journal of the European Union, C 383. DOI: 10.2864/084739.

9. European Parliament (2014) Mapping Smart Cities in the EU, [Online], Available: http://www.europarl.europa.eu/studies [07 Feb 2020].

10. Falconer, G. and Mitchell, S. (2012) Smart City Framework - A Systematic Process for Enabling Smart+Connected Communities, [Online], Available: http://www.cisco.com/web/about/ac79/docs/ps/motm/Smart-City-Framework.pdf [17 Feb 2020].

11. Giffinger, R., Fertner, C., Kramar, H., Meijers, E. and Pichler-Milanovic, N. (2007) "City-ranking of European medium-sized cities", European Smart Cities.

12. Guvernul României (2014) Hotătâre nr. 929 privind aprobarea Strategiei naţionale de cercetare, dezvoltare şi inovare 2014- 2020, [Online], Available: http://www.cdi2020.ro/wpcontent/uploads/2014/10/HOT\%C4\%82R\%C3\%82RE-nr-929-din-21-octombrie-2014-privindaprobarea-Strategiei-na\%C5\%A3ionale-de-cercetare-dezvoltare-\%C5\%9Fi-inovare-2014-2020.pdf [02 May 2020].

13. Halegoua, G. (2020) Smart Cities, The MIT Press Essential Knowledge Series, Cambridge.

14. Hollands, R. (2008) "Will the real smart city please stand up? - Intelligent, progressive or entrepreneurial?", City - Analysis of Urban Change, Theory, Action, Vol. 12, No. 3, pp. 303- 320. DOI: 10.1080/13604810802479126.

15. HVB Communicatie Amsterdam (2017) Smart Cities in Europe, [Online], Available: http://www.smartcitiesineurope.com/ [18 Feb 2020].

16. IBM (2012) Cities are reaching their limits, [Online], Available: https://www03.ibm.com/press/us/en/photo/39432.ws [20 Feb 2020].

17. Krugman, P. (1991) "Increasing Returns and Economic Geography", Journal of Political Economy, Vol. 99, No. 3, pp. 483-499. DOI: 10.1086/261763.

18. McGuire, M. (2018) "Beyond flatland: when smart cities make stupid citizens", City, Territory and Architecture, Vol. 5, No. 22. DOI: 10.1186/s40410-018-0098-0.

19. MCSI (2014) Strategia Națională privind Agenda Digitală pentru România: Digital Agenda 20142020 for Romania, [Online], Available: https://www.comunicatii.gov.ro/agenda-digitala-pentruromania-2020 [01 Oct 2020].

20. MCSI (2016) SMART CITY FOR SMART COMMUNITIES, [Online], Available: https://www.comunicatii.gov.ro/mcsi-a-lansat-ghidul-smart-city-pentru-romania/ [20 Jan 2020].

21. Mock, J. (2016) "Smart City-Stupid Countryside". In Mock, J., Kawamura, H. \& Naganuma, N. (eds.) The Impact of Internationalization on Japanese Higher Education. Global Perspectives on Higher Education, Vol. 22, pp. 191-206, SensePublishers, Rotterdam. DOI: 10.1007/978-94-6300-169412.

22. OECD (2015) The Metropolitan Century: Understanding Urbanisation and its Consequences, OECD Publishing, Paris. DOI: 10.1787/9789264228733-en.

23. Pușcașu, B. (2016) Mic ghid pentru orașele care vor să devină (și mai) inteligente, [Online], Available: http://www.aapro.ro/doc/articole/2016-10-28/ghid-smart-cities-ro.pdf [10 Feb 2020].

24. Romanian Association for Smart City and Mobility (2019) Romanian Association for Smart City. Home page, [Online], Available: https://romaniansmartcity.ro/ [10 Mar 2020].

25. Russo, F., Rindone, C., and Panuccio, P. (2014) The process of smart city definition at EU level, WIT Transactions on Ecology and the Environment, Vol. 191, pp. 979-989, WIT Press, Southampton. DOI: $10.2495 /$ SC140832.

26. Schaffers, H., Komninos, N., Pallot, M., Trousse, B., Nilsson, M., and Oliveira, A. (2011) "Smart Cities and the Future Internet: Towards Cooperation Frameworks for Open Innovation". In Domingue, J., Galis, A., Gavras, A, Zahariadis, T., Lambert, D., Cleary, F., Daras, P., Krco, S.,, Müller, H., Li, M., Schaffers, H., Lotz, V., alvarez, F., Stiller, B., Karnouskos, S., Avessta, S. \& Nillson, M. (eds.) The Future Internet - Future Internet Assembly 2011: Achievements and Technological Promises, pp. 431446, Springer-Verlag, Berlin. DOI: 10.1007/978-3-642-20898-0_31.

27. Smart Cities of Romania (2019) Smart Cities of Romania, Home page, [Online], Available: https://romaniasmartcities.ro/ [26 Feb 2020].

28. SmartCityPlatform (2018) What it means to be a smart city?, [Online], Available: http://en.smartiscity.eu/what-it-means-to-be-a-smart-city/ [01 Mar 2020]. 
29. Sterling, B. (2018) Stop Saying 'Smart Cities'. Digital stardust won't magically make future cities more affordable or resilient, [Online], Available: https://www.theatlantic.com/technology/archive/2018/02/stupid-cities/553052/ [12 Mar 2020].

30. Trip, D. and Badulescu, D. (2020) Touchless Tourism - How new tourism will look like, Oradea, 11th Edition of Griffiths School of Management and IT Annual Conference - GSMAC 2020.

31. United Nations Development Programme (2020) Goal 11: Sustainable cities and communities, [Online], Available: https://www.undp.org/content/undp/en/home/sustainable-development-goals/goal11-sustainable-cities-and-communities.html [02 Mar 2020].

32. Vrabie, C., Dumitrascu, E. (2018) Smart Cities - de la idee la implementare sau despre cum tehnologia poate da strălucire mediului urban, Editura Universul Academic, București.

33. William, J. (2013) Smart Cities, [Online], Available: https://smartcities.media.mit.edu/frameset.html [10 Mar 2020]. 